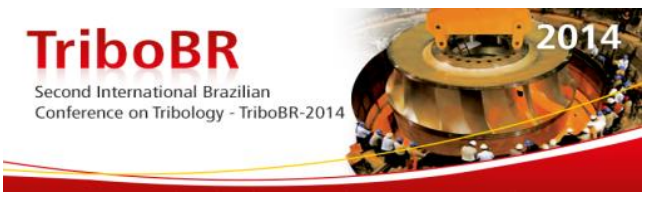

\title{
EXPERIMENTAL EVALUATION OF THE METHOD AIR SCOURING USED IN FLUSHING SYSTEMS FOR CLEANING PIPES*
}

\author{
Vitor Orlando Ferreira ${ }^{1}$ \\ Richard de Medeiros Castro² \\ Elvys Isaias Mercado Curi ${ }^{3}$ \\ João da Silva Júnior ${ }^{4}$
}

\begin{abstract}
The efficiency of an apparatus which uses a forced lubrication system, as well as the useful life of its components, is strongly related to the degree of contamination of lubricating oil. The presence of contaminants and the degradation of the oil itself cause it to release substances that fouling of the wall of the pipes. The cleaning and dialysis of the oil pipes, besides prolonging the life of the lubricant reduces wear of the components. There are several methods of cleaning in pipes, the problem is that some have abrasive characteristics, which could damage some types pipes. Among the non-abrasive methods stand the Flushing and Air scouring. Flushing uses the lubricating oil which circulates in temperatures alternating and high speeds, for generating turbulence to perform washing. The Air scouring method uses oil and filtered compressed air, injected into pipe, to generating higher flow, causing the power supply unit with fluid can work with lower power consumption and higher speeds, removing fouling of the pipe. The objective of this research is to evaluate the Reynolds number to correlate with the efficiency of cleaning the pipe. The method applied was the Air scouring and it was verified that the qualitative effects may occur when compared to Flushing. After testing, it was found that the chosen method brings significant changes in flow, and this flow regime varies considerably increasing the Reynolds number.
\end{abstract}

Keywords: Contamination; Cleaning; Flushing; Air scouring.

1 Graduate student, Student, School of Engineering, Department of Mechanic Engineering, Laboratory of the Vibration and Tribology (LAVITRI), Faculty SATC, Criciúma, Santa Catarina, Brazil.

2 Master, Teacher/ researcher, School of Engineering, Department of Mechanic Engineering, Laboratory Automation and Simulation of Hydraulic and Pneumatic Systems (LASPHI), Faculty SATC, Criciúma, Santa Catarina, Brazil.

3 Doctor, Teacher/ researcher, School of Engineering, Department of Mechanic Engineering, Laboratory of the Vibration and Tribology (LAVITRI), Faculty SATC, Criciúma, Santa Catarina, Brazil.

4 Graduate student, Student, School of Engineering, Department of Mechanic Engineering, Laboratory Automation and Simulation of Hydraulic and Pneumatic Systems (LASPHI), Faculty SATC, Criciúma, Santa Catarina, Brazil.

\footnotetext{
* Technical contribution to the $2^{\text {nd }}$ International Brazilian Conference on Tribology - TriboBR 2014, November $3^{\text {rd }}$ to $5^{\text {th }}$, 2014, Foz do Iguaçu, PR, Brazil.
} 


\section{INTRODUCTION}

The life of mechanical components using lubrication to reduce or prevent wear, depend heavily on the efficiency of lubrication. In steam turbines, the highest occurrences of faults and wear are produced by deficiencies of lubrication. For example, it was reported that the turbines are responsible for $20 \%$ of the failures in a conventional plant, of which $19 \%$ of the problems are related to their lubrication [1]. The lubrication systems are exposed to many types of contamination such as water, air oxidation, acids, bacteria and solid particles. The presence of solid contaminants in the system produces fouling in pipes, and some of these problems directly influence the efficiency and premature wear of the equipment, especially the filters. To avoid these problems, it is necessary to routinely clean the pipe. Today, the most widely used method for cleaning the pipes lubricating oil routine is Flushing. However, there are other more abrasive cleaning methods, however, when these methods are used in steel pipes, the process should be followed by the use of coatings, otherwise corrosion can occur at an accelerated rate [2].

Studies show that 75 to $85 \%$ of the failures occurring in hydraulic systems are connected directly to the contamination. Due to the clearances are minimum in modern hydraulic systems, even with particles invisible to the naked eye, can lead to early wear of a component and increase the loss efficiency of the whole system. Any preventive intervention becomes necessary in equipment hydraulic systems, emphasize the need for cleaning pipes and components for the removal of contaminants. These contaminants may appear in hydraulic systems in three ways: solid (particles ranging from 0 to $5 \mu \mathrm{m}$ ), liquids (free and dissolved water), air (aeration in the hydraulic circuit) [3].

Contamination of hydraulic systems usually occurs by the admission of contaminants from external sources, the metal loss from the wear of moving components and the continuous process of chemical degradation of the hydraulic lubricating oil, resulting in the formation of harmful acidic sludge system. These are some of the factors that make the physical and chemical monitoring of hydraulic lubricating oils is an important tool in combating corrective and unscheduled maintenance shutdowns in production, generating substantial losses for industries [4].

For cleaning pipes lubrication of turbines in general, applies to ASTM D6439 [5], which establishes guidelines for the conduct Flushing, of which the main recommendations are: for any lubricant oil used in cleaning, the flow is turbulent, ensuring that the Reynolds number of the fluid is increased to 4000Re, without exceed the temperature of $70^{\circ} \mathrm{C}$, and few times changing to oil cold. The objective is to have a turbulent flow, which is capable of removing particulate contaminants and waste pipes quickly decrease the operating time for cleaning and increase the efficiency of the process. Despite the lack of information in the literature regarding the Air scouring method for oil-hydraulic systems, it was found through preliminary results that the method can meet the requirements with regard to increasing the Reynolds number, obtaining gains not only cleaning efficiency, but decreased in the drive power of the equipment for systems of Flushing [6].

This research deals with the study for more efficient internal cleaning of pipes, knowing its importance for the efficiency of the machines. The objective of this research is to add the injection of compressed air in Flushing pipe that uses as a cleaning system, this mixture of air with fluid that circulates is called Air scouring.

\footnotetext{
* Technical contribution to the $2^{\text {nd }}$ International Brazilian Conference on Tribology - TriboBR 2014, November $3^{\text {rd }}$ to $5^{\text {th }}$, 2014, Foz do Iguaçu, PR, Brazil.
} 


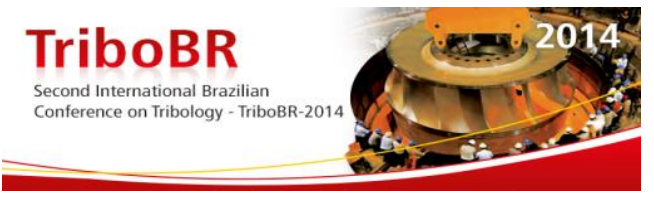

\section{MATERIAL AND METHODS}

For the study and comparison of Flushing procedure accompanied by the Air scouring procedure was developed a testing bench containing a reservoir, a pump and pipes through which circulates the oil, and an injection nozzle for compressed air, to evaluate the parameters related to the Reynolds number. Thus it will be possible to determine pipe diameters, the speed only with the oil, the speed of mixing air and oil, the oil viscosity at room temperature and the correlation of air pressure with the oil in the mixture for various pressures.

Another important aspect is the visual evaluation of the behavior of the oil with and without air, because a turbulent flow is laminar or to a different transition behavior. To this, the bench pipe was transparent, making it possible to identify qualitatively the behavior of the fluid.

\subsection{List of Materials Used}

To build the test bench, the following materials and components mechanical were used, as presented in Table 1.

Table 1. Components used in the test bench

\begin{tabular}{|l|l|}
\hline Oil tank - 85 liters & Ball valve - 25mm \\
\hline Hydraulic oil - ISO VG 68 - HLP & Hydrometer - reading in $\mathrm{m}^{3}$ \\
\hline Electric motor 0.5 HP - 1370 rpm & Graduated container - 18 liters \\
\hline Gear Pump - $19 \mathrm{~cm}^{3}$ / rev. & Check valve - $13 \mathrm{~mm}$ \\
\hline Valve lever 01 Stage - 60LPM & Aluminum tube - $1.2 \mathrm{~mm}$ \\
\hline Level Display with Thermometer & Laser Thermometer - máx. 250C \\
\hline Acrylic Tube - Øi22 mm & Tachometer - máx. $10000 \mathrm{rpm}$ \\
\hline Gauge - Oil and compressed air & Digital chronometer \\
\hline
\end{tabular}

\subsection{Development of Bench Tests}

To develop the test bench, was performed a manufacturing design using solid modeling of all mechanical components, through the SolidWorks ${ }^{\circledR}$. Moreover, was implemented the model commercial acrylic pipes to determine the best position at the time of actual implementation of the components used. In Figure 1 below is presented the model of the test bench that was used to perform the experiment.
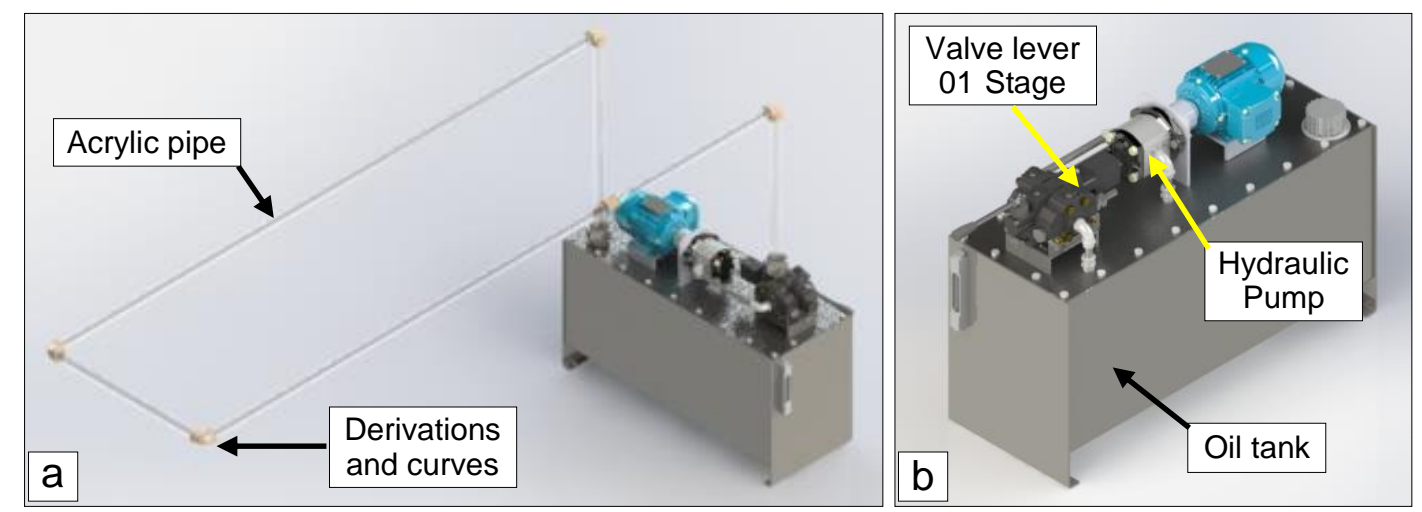

Figure 1. Design in 3D of the test bench. (a) acrylic tubing installed, (b) reservoir components

\footnotetext{
* Technical contribution to the $2^{\text {nd }}$ International Brazilian Conference on Tribology - TriboBR 2014, November $3^{\text {rd }}$ to $5^{\text {th }}$, 2014, Foz do Iguaçu, PR, Brazil.
} 

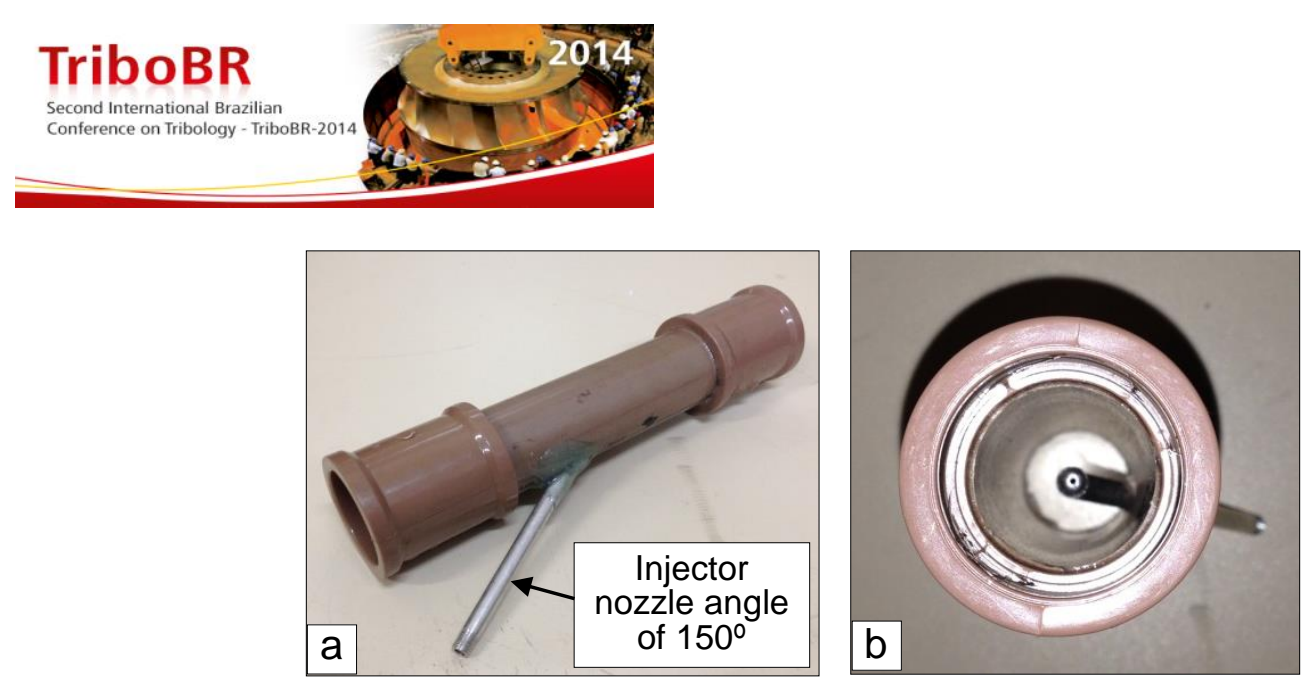

Figure 6. Injection system of compressed air. (a) 3D view, (b) top view and inside

During the initial phase of testing bench has needed install a check valve on the outlet of the filter, because the oil returned was into the filter regulator, or when he was at a higher pressure than that of air, causing further damage additional to the filter (Figure 7b).

As the acrylic pipe, according to data provider is limited to a pressure of 5.5 bar and the pressure of work would be up to 3 bar, we used pressure gauges with up to 4 bar of the scale full, providing minor errors reading at low pressures. In Figure 7(c), the methodology adopted for fixing the gauges and directions of flows of mineral oil is presented.
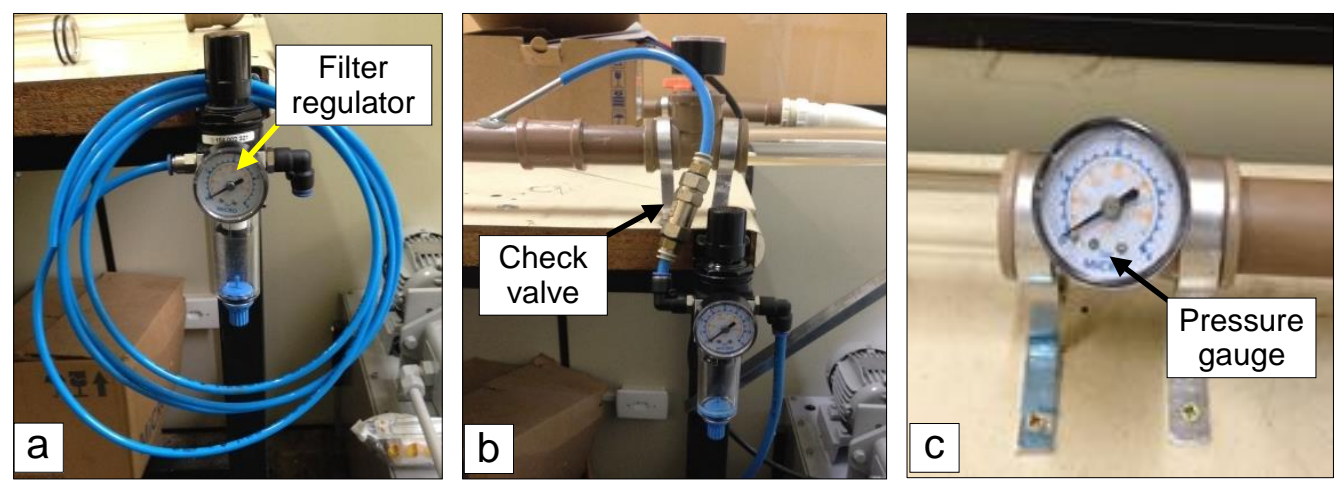

Figure 7. Injection of compressed air system. (a) filter regulator, (b) Check valve, (c) pressure gauge

\subsection{Data Collecting System}

For measurement of oil flow, without air, has placed a graduated container, 18 liters at the end of the circuit (see Figure 8) for measuring the volume adaptation takes place on the vessel, controlling the time that it takes filling in from 1 to 10 liters, so, is obtained the volume a function of time $(\mathrm{t})$.

To have different values for the flow and study the parameters that relate this magnitude that is proportional to velocity, evaluating the Reynolds number, we used a frequency inverter to change the engine speed, because the flow is the product of the geometric displacement of the pump for its rotation [7]. With this modification, we could do testing on three certain speeds, which were, 570, 800 and $1370 \mathrm{rpm}$, obtaining three different flow rates. Velocities were obtained by measurement with tachometer and also expressed by frequency inverter. All data were collected manually.

The volume of the mixture of oil and air out of the pipe was measured by a hydrometer, and tests were made both for visualizing the volume of oil as in air

* Technical contribution to the $2^{\text {nd }}$ International Brazilian Conference on Tribology - TriboBR 2014, November $3^{\text {rd }}$ to $5^{\text {th }}$, 2014, Foz do Iguaçu, PR, Brazil. 


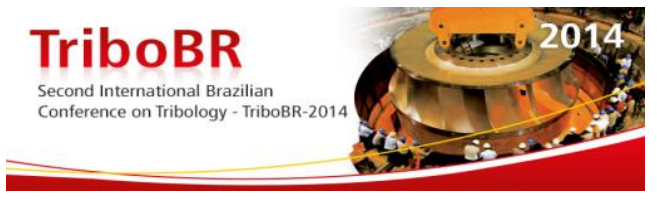

volume. It was possible to clearly visualize the differences in flow measurements with and without air mixture, after several trials with both measures.

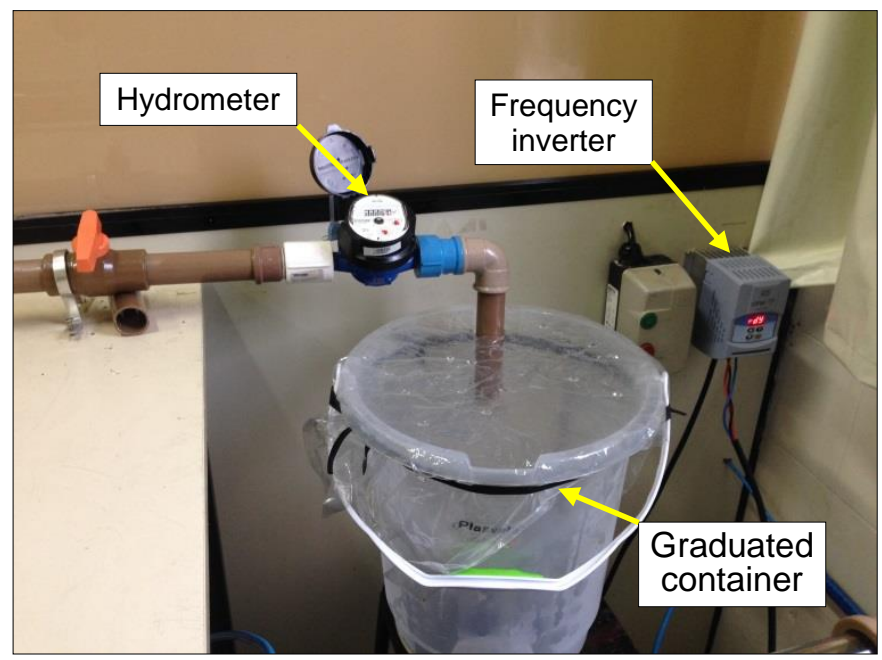

Figura 8. Data collection system used in the tests

The analysis was performed by reading the collected data. After the data were entered into Excel software, generating tables and graphs based on the equations of fluid mechanics, as the Equation 1 [8], for volumetric flow and also to the Reynolds number (Equation 2) [7].

$$
Q=v \cdot A \rightarrow Q=v \cdot\left(\frac{\pi \cdot d^{2}}{4}\right)
$$

Where:

$Q\left[\mathrm{~m}^{3} / \mathrm{s}\right]:$ Volumetric flow

$A\left[\mathrm{~m}^{2}\right]$ : Pipe section

$v[\mathrm{~m} / \mathrm{s}]:$ Fluid velocity

$d[\mathrm{~m}]:$ pipe diameter

$$
\operatorname{Re}=\frac{v \cdot D}{v}
$$

Where:

$\operatorname{Re}[---]:$ Reynolds number

$D\left[\mathrm{~m}^{2}\right]$ : Pipe section

$v[\mathrm{~m} / \mathrm{s}]:$ Fluid velocity

$v\left[\mathrm{~m}^{2} / \mathrm{s}\right]$ : pipe diameter

In all timing data, concepts of descriptive statistics of mean and standard deviation were applied so that the data collected were reliable. The uncertainties were small generating reliable results during application of calculations and modeling of graphics.

\section{RESULTS AND DISCUSSION}

Based on the collected data, has obtained the results presented, through which these graphs were generated for better visualization of the effect caused by air when injected into the pipe.

The results with values reported at speeds set at $570 \mathrm{rpm}$ pump, which was determined during the process, are presented in Figure 9 Through the curve can be

* Technical contribution to the $2^{\text {nd }}$ International Brazilian Conference on Tribology - TriboBR 2014, November $3^{\text {rd }}$ to $5^{\text {th }}$, 2014, Foz do Iguaçu, PR, Brazil. 
seen a small flow variations during testing, it is still possible to view the disturbance caused by air during the passage of oil in the transparent pipe.

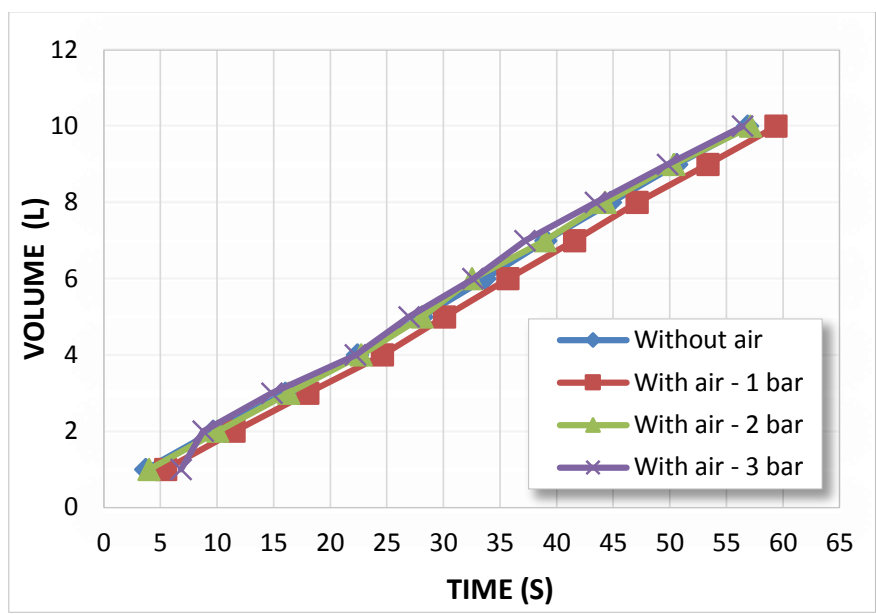

Figure 9. Variation of volume vs. time for a rotation of $570 \mathrm{rpm}$ motor

The Figure 10 shows values of the speeds encountered during the process where the pump speed was set to $800 \mathrm{rpm}$. In this test, is observed greater cohesion, the volume change by time.

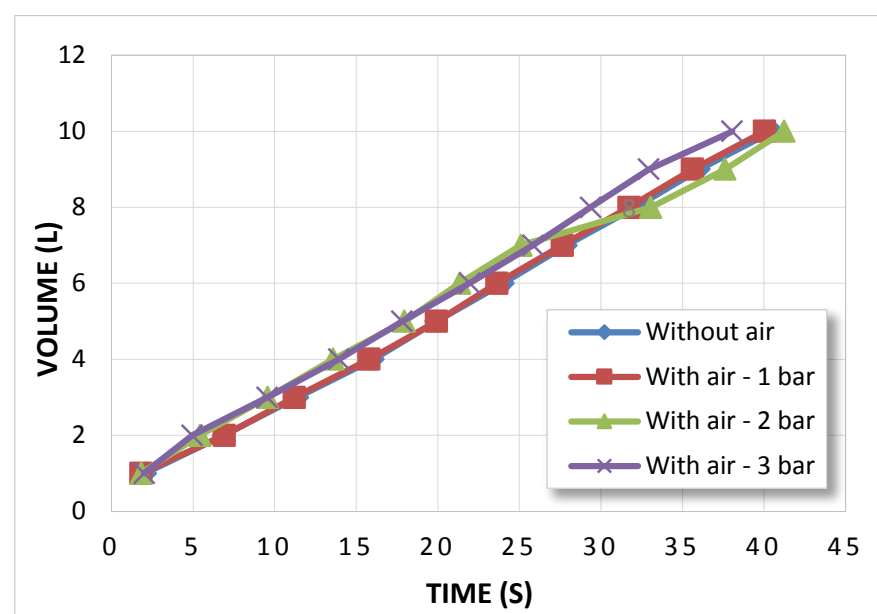

Figure 10. Variation of volume vs. time for a rotation of $800 \mathrm{rpm}$ motor

The Figure 11 shows values of the speeds encountered during the process where the pump speed was set to $1370 \mathrm{rpm}$. In this graph, we can see that the flow changes considerably from each other, the greater the pressure, the line is at higher levels, showing that the speed tends to change significantly when injecting air.

* Technical contribution to the $2^{\text {nd }}$ International Brazilian Conference on Tribology - TriboBR 2014, November $3^{\text {rd }}$ to $5^{\text {th }}$, 2014, Foz do Iguaçu, PR, Brazil. 

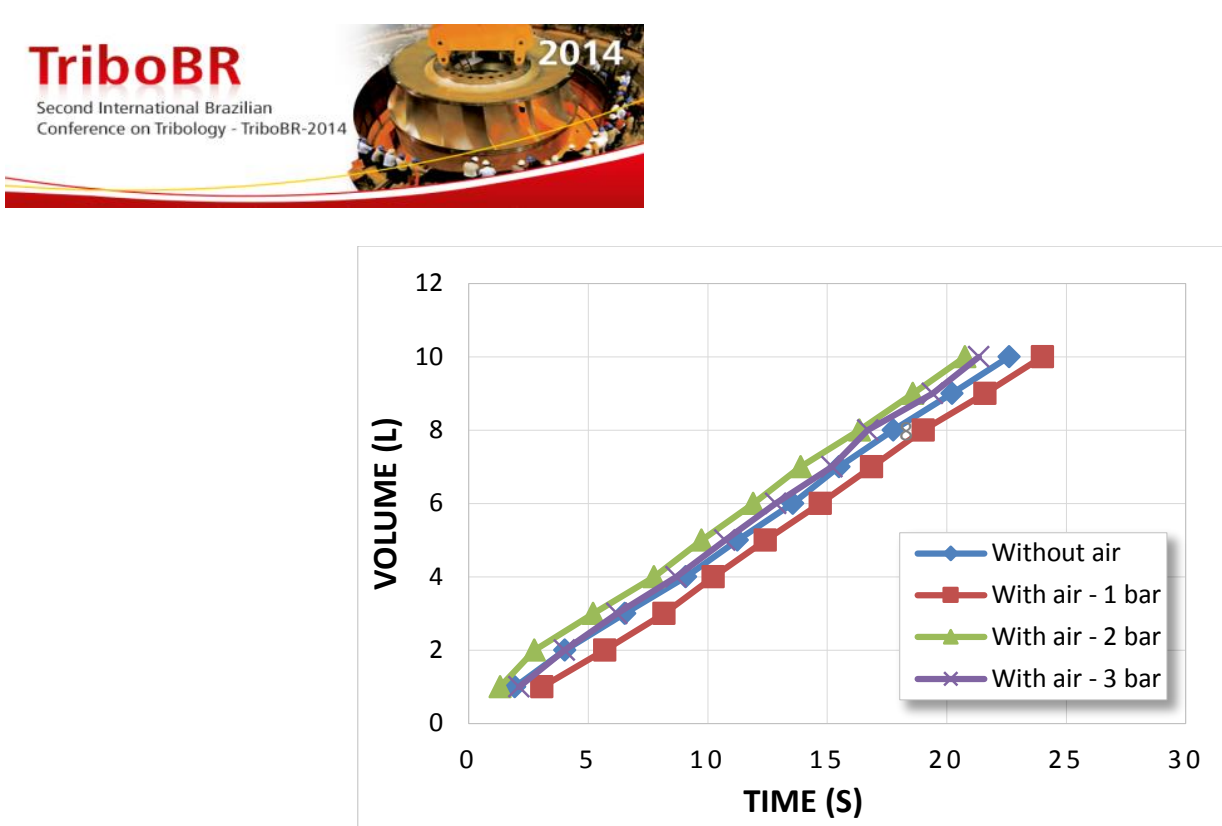

Figure 11. Variation of volume vs. time for a rotation of $1370 \mathrm{rpm}$ motor

The trend of the curves in Figure 9 are almost the same, which means that the oil flow has hardly changed with the injection of air (flow rate $=$ volume $/$ time - trend line). The increased level indicates that the additional pressure air, changed system power perhaps under the influence of air pressure. Only in 3 bar for the time for the 10 liters was smaller than the other results.

In Figures 10 and 11, to a pressure of 1 bar, the curve is below only with oil, which means that the pressure influences without generating benefit by intake air, accordingly the time was increased to 10 liters. While the pressure 2 to 3 bar in Figure 9 time was shorter, realizing little change.

Qualitatively, it is observed that for lower air pressures (1 to 2 bar), and the oil does not mix the air, leaving the air bubbles, with the passage of time and the length of the tube stood on upper tube. To a mixture of 3 bar with air bubbles occurred in a similar fashion as oil pump cavitation occurs.

From the graphs shown it was possible to find the value of flow, and hence the fluid velocity, since the diameter of the pipe remained constant. Through the calculated speed, was determined the Reynolds number for each prescribed speed and pressure. The results are shown in Table 2.

Tabela 2. Acquired values for air pressure and predetermined rotations

\begin{tabular}{|c|c|c|c|c|c|}
\hline \multirow{2}{*}{$\begin{array}{l}\text { Collected data } \\
\text { and Calculated }\end{array}$} & \multirow{2}{*}{$\begin{array}{l}\text { Revolution } \\
\quad(\mathrm{rpm})\end{array}$} & \multicolumn{4}{|c|}{ Air pressure injected (bar) } \\
\hline & & 0 & 1 & 2 & 3 \\
\hline \multirow{3}{*}{$\begin{array}{l}\text { Volume } \\
\text { (L) }\end{array}$} & 570 & 9,5 & 9,7 & 11,9 & 13,1 \\
\hline & 800 & 9,4 & 10,2 & 11,5 & 12,3 \\
\hline & 1370 & 9,8 & 10,2 & 11,6 & 12,4 \\
\hline \multirow{3}{*}{$\begin{array}{l}\text { Flow } \\
(\mathrm{L} / \mathrm{s})\end{array}$} & 570 & 0,17 & 0,16 & 0,21 & 0,23 \\
\hline & 800 & 0,23 & 0,25 & 0,28 & 0,32 \\
\hline & 1370 & 0,43 & 0,42 & 0,56 & 0,58 \\
\hline \multirow{3}{*}{$\begin{array}{l}\text { Speed } \\
(\mathrm{m} / \mathrm{s})\end{array}$} & 570 & 0,44 & 0,43 & 0,55 & 0,61 \\
\hline & 800 & 0,61 & 0,67 & 0,73 & 0,85 \\
\hline & 1370 & 1,14 & 1,12 & 1,47 & 1,53 \\
\hline \multirow{3}{*}{$\begin{array}{c}\text { Reynolds } \\
\text { number } \\
\text { (adm.) }\end{array}$} & 570 & 142 & 139 & 177 & 166 \\
\hline & 800 & 198 & 217 & 237 & 275 \\
\hline & 1370 & 369 & 362 & 476 & 495 \\
\hline
\end{tabular}

* Technical contribution to the $2^{\text {nd }}$ International Brazilian Conference on Tribology - TriboBR 2014, November $3^{\text {rd }}$ to $5^{\text {th }}$, 2014, Foz do Iguaçu, PR, Brazil. 


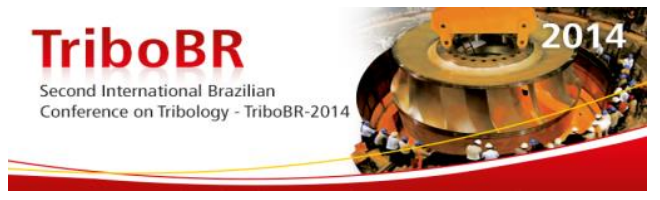

According to the data in Table 2, it was possible to graph the Figure 12, whereby it is possible to visualize the variation of Reynolds number with respect to the variable speed electric motor, and view the three options of compressed air pressure injected into the pipe.

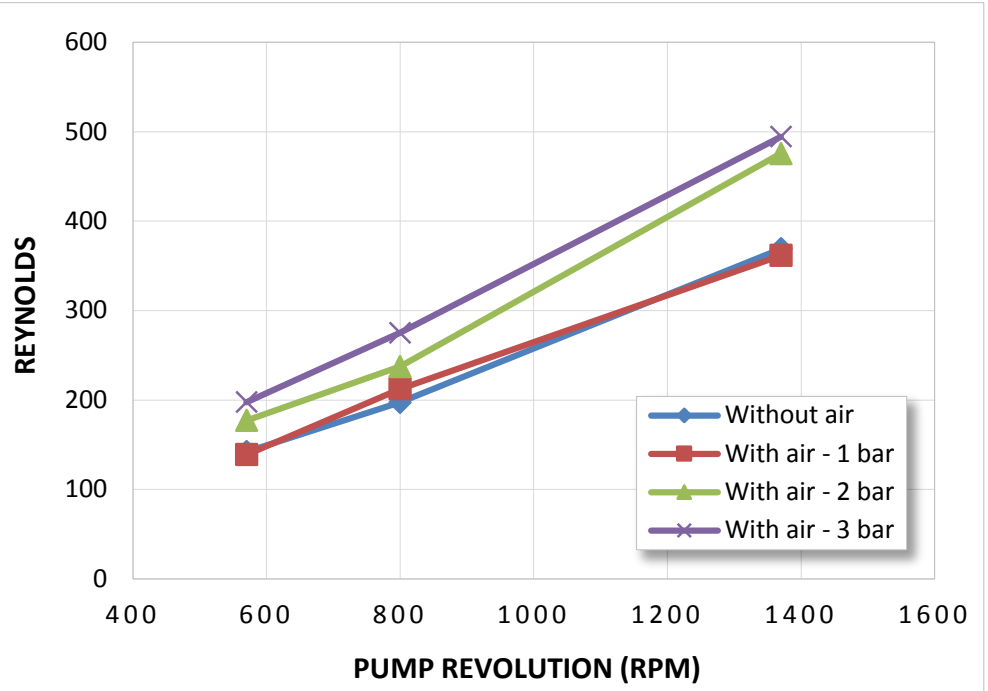

Figure 12. Reynolds variation with injection of compressed air and also the speed of the pump

From the analysis of Figure 12, which shows the results of all the experiments, as a function of Reynolds number, it is observed that for the same flow rate of the pump there is a large variation of the Reynolds number as a function of injected air. For the 2 and 3 bar pressure at a speed of $1370 \mathrm{rpm}$ pump, the increase of the Reynolds number was 28.8 and $34 \%$, respectively. With pressure of 1 bar occurred a decrease of $1.9 \%$. Less than or equal to the oil pressure can reduce the Reynolds number, perhaps due to the fact that it impedes the movement of the oil with the air.

It is noteworthy that the temperatures collected remained at $18^{\circ} \mathrm{C}$ for all tests. Whereas the oil viscosity is proportional to the temperature, one can disregard that there has been a change in this parameter.

The quantitative results show that injecting air into the system is an increase in velocity up to $34.03 \%$ when compared with the circulation of fluid only supported by the hydraulic pump, or only the displacement of mineral oil.

\section{CONCLUSION}

As already mentioned in previous chapters, the Air scouring method, applied to a stream of oil, is a topic that has not been explored, so the research seeks to gather information on the advantages and disadvantages of this method.

The test rig allowed evaluating the main parameters of the oil flow, velocity, viscosity behavior, with and without air flow and finally the Reynolds number. The change of pump speeds afforded measurements with different flow rates, with and without air that mixes with the oil.

The mixture of air with oil at low pressures (1 bar) decreased slightly the Reynolds number on the counter, while which 2 bar, an increase occurs the Reynolds number on the bench. In low speeds, air goes to the area above pipes and oil concentrated down. In pressure 3 bar occurred a mixture air with oil (small air bubbles that are distributed in oil), both at low and at high speed. The pressure and velocity, greater

* Technical contribution to the $2^{\text {nd }}$ International Brazilian Conference on Tribology - TriboBR 2014, November $3^{\text {rd }}$ to $5^{\text {th }}$, 2014, Foz do Iguaçu, PR, Brazil. 


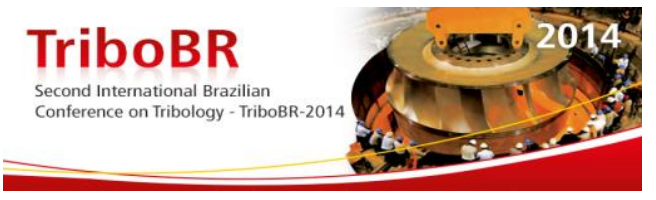

was the effect of the foam. Probably the effect of controlled cavitation is favorable for cleaning pipes.

Both the fluid used as control of fluid lubrication oil temperature is a factor to increase the Reynolds Number, because increasing the temperature would decrease the viscosity which is inversely proportional to Reynolds, causing it to rise significantly. With increasing fluid velocity, was identified a better result in increasing the Reynolds number with the injection of compressed air.

\section{Acknowledgments}

The authors thank the companies ICON - Machinery and Equipment SA and College SATC, for financial support, to Professor Luiz Carlos Cavaler Coordinator, colleagues and students of Mechanical Engineering, Daniel Medeiros, João da Silva Junior and Yan Medeiros Morona, for their valuable contributions, during the development of this work.

\section{REFERENCES}

1 Terradillos $\mathrm{J}$, Todo sobre la lubricación de las turbinas y su mantenimiento a traves del análises de aceite, Ingeniería y gestión de mantenimiento: una nueva visión del mantenimiento. 2003; 32: 59-67.

2 Vitanage D, Pamminger F, Vourtsanis T. Safe Piped Water. Maintenance and Survey of Distribution Systems. Ed. IWA publishing. London, UK, 2004.

3 Vieira, AD. et al. Controle de Contaminação para Fluidos Lubrificantes. $27^{\text {th }}$ Encontro nacional de engenharia de produção; 2007 oct 09-11; Foz do Iguaçu, Brazil: ENEGEP, 2007. p. 1-8.

4 Neiva J. Conheça o Petróleo, Ed. Expressão e Cultura. Rio de Janeiro, Brazil, 1974;

5 ASTM D6439-11, Standard Guide for Cleaning, Flushing, and Purification of Steam, Gas, and Hydroelectric Turbine Lubrication Systems, Philadelphia, PA. International ASTM, 1999.

6 Muhammad H, Al-Malack GK. Cleaning Techniques of Dynamic Membranes. Separation and Purification Technology Series, Elsevier Sience Publishers, 1997; 12, p.25-33.

7 Linsingen I V. Fundamentos de Sistemas Hidráulicos. Ed. UFSC, Florianópolis, SC, Brazil, 2008.

8 Fox, RW, MCDonald, AT, Pritchard, PJ., Introdução à Mecânica dos Fluidos, Ed. Livros Técnicos e Científicos S.A., Rio de Janeiro, RJ, Brazil, 2006.

* Technical contribution to the $2^{\text {nd }}$ International Brazilian Conference on Tribology - TriboBR 2014, November $3^{\text {rd }}$ to $5^{\text {th }}$, 2014, Foz do Iguaçu, PR, Brazil. 